\title{
Host-plants of leaf-miners in Australian subtropical rainforest
}

\section{Sarah C Maunsell $^{1 *}$, Chris J Burwell ${ }^{1,2}$, Rebecca J Morris ${ }^{3}$, William JF McDonald ${ }^{4}$, Edward D Edwards ${ }^{5}$, Rolf G Oberprieler ${ }^{5}$ and Roger L Kitching ${ }^{1}$}

${ }^{1}$ Griffith School of Environment \& Environmental Futures Research Institute, Griffith University, Nathan campus, Kessels Road, QLD 4111, Australia

${ }^{2}$ Biodiversity Program, Queensland Museum, South Brisbane, QLD 4101, Australia

${ }^{3}$ Department of Zoology, University of Oxford, South Parks Road, Oxford, OX1 3PS, United Kingdom

${ }^{4}$ Queensland Herbarium, Queensland Government Department of Science, Information Technology and Innovation, Brisbane Botanic Gardens - Mt Coot-tha, Toowong, QLD, 4066, Australia

${ }^{5}$ CSIRO National Research Collections Australia, Australian National Insect Collection, GPO Box 1700, Canberra, ACT 2601, Australia

*S.Maunsell@griffith.edu.au

\begin{abstract}
Leaf-miners are endophytic insect herbivores that are considered to be relatively host-specific compared with other types of insect herbivores, often depending on one or a few congeneric hosts. Due to their degree of host-specificity, they may be particularly vulnerable to environmental change. Despite this, little is known about the host-plants and life histories of the Australian leaf-mining fauna. Here, we present new information on the host-plant use of leaf-miners occurring in Australian subtropical rainforest. We repeatedly hand-collected leafminers at 14 sampling sites within the 'Tweed Caldera' subtropical rainforest region of southeastern Queensland and north-eastern New South Wales, Australia. Leaf-miners and their host-plants were identified to species (or morphospecies in the case of some leaf-miners). Within the region, a total of 106 plant species was recorded as leaf-miner hosts, on which a total of 12679 individual leaf-miners was counted, belonging to 50 different species. We measured the local host-plant range of each leaf-miner species for which we had reliable incidence records across sampling sites (24 species). Local host-specificity was relatively high with $66.7 \%$ of species recorded from a single or two congeneric host-plants. $16.7 \%$ of
\end{abstract}


species were restricted to a single plant family and $16.7 \%$ were recorded on a few to several plants within the same plant order or across a range of unrelated host-plants.

Key words: herbivory, host specificity, insect-plant interactions

\section{Introduction}

Leaf-miners are herbivorous insects that pass their larval stages inside the leaf of their hostplant, using it as a permanent 'captured' food source, a strategy that occurs among Lepidoptera, Diptera, Coleoptera and Hymenoptera (Hespenheide 1975). Little is known about the ecology of leaf-miners occurring in natural ecosystems in Australia (Sinclair \& Hughes 2010), and even less is known about species inhabiting rainforest. Basset (1991) recorded leaf-miner damage on the rainforest tree Argyrodendron actinophyllum (Malvaceae) in subtropical rainforest at Lamington National Park in south-eastern Queensland. Four species of Roscidotoga Hoare (Lepidoptera: Nepticulidae), which mine plants of the order Oxalidales, have been collected and described from eastern Australian rainforest, including from Lamington and Border Ranges National Parks (Hoare 2000, van Nieukerken 2011, Hoare \& van Nieukerken 2013).

As part of a larger study including other forest types, Sinclair \& Hughes (2008) recorded the incidence of leaf-mining on trees at six rainforest sites along the east Australian coast, between Sydney and Broken Head $\left(28^{\circ}-33^{\circ} \mathrm{S}\right.$, New South Wales). In their study, for $89 \%$ of thirty-six mined plant species no previous records of leaf-mining existed, indicating how little is known about the range of plants mined by insects in Australia (Sinclair \& Lesley 2008). Beyond rainforest communities, Bairstow et al. (2010) recorded ninety-seven leaf-miner morphospecies (using mine shape as an indication of identity) on forty-six different species of Acacia along a rainfall gradient from eastern to western New South Wales. Lambkin et al. (2008) reared three different agromyzid flies and their parasitoids from three plant species (two Asteraceae and one Plantaginaceae) around the Canberra region.

Some host-plants of leaf-miners are listed in 'Moths of Australia' (Common 1990), 'Insects of Australia' (Naumann 1991) and scattered through the taxonomic literature (see for example Spencer 1977; Kaila 2011; Pullen et al. 2014; van Nieukerken \& Geertsema 2015). Kaila 
(2011), for example, described many leaf-mining associations in elachistine moths, which mine monocotyledonous plants. Some host-plant information is also attached to specimens of leaf-miners deposited in collections such as the Australian National Insect Collection (ANIC). Here we present new information on the host-plant use of leaf-miners occupying subtropical rainforest in Australia. These data were obtained during a wider study that investigated the effects of elevation on the diversity and composition of leaf-miners and their interactions with host-plants (Maunsell et al. 2016) as well as the food web structure of leaf-miners and their parasitoids (Maunsell et al. 2015).

\section{Materials and Methods}

During 2011 and 2012, leaf-miners and their host-plants were sampled in Australian subtropical rainforest at fourteen sites, situated at elevations between 260 and $1160 \mathrm{~m}$ above sea level (see Supplementary Material Table S1). Four sites were situated in Lamington National Park in south-eastern Queensland (Qld), nine in Border Ranges National Park and one in Mebbin National Park in north-eastern New South Wales (NSW) $\left(28^{\circ} \mathrm{S}, 153^{\circ} \mathrm{E}\right)$. We sampled all sites for leaf-miners in August and October 2011 and February and May 2012, apart from two low-elevation sites (approximately $300 \mathrm{~m}$ ), which were not sampled in August. Five sites within the Border Ranges National Park were also additionally sampled in December 2011 and April 2012 (see Supplementary Material, Table S1).

On each sampling occasion, leaf-miners were sampled by examining all plants along eight 50-by-3 m transects (a total of $1200 \mathrm{~m}^{2}$ ) at each site. Leaves with active mines were removed from the plant, and the host-plant species was identified in the field or later from a pressed specimen. Leaf-miners (larvae and/or pupae) were reared to adults, mounted or stored in ethanol, sorted into morphospecies and then identified to species where possible. Leaf-miners that were not reared were assigned to species or morphospecies based on a combination of host-plant and mine structure. Some of the lepidopteran leaf-miners were DNA barcoded in order to confirm identifications. Two legs were removed from pinned specimens and crushed. DNA extractions were performed using a modified spin column extraction protocol (Epoch Life Sciences). The mtDNA cytochrome C oxidase 1 (CO1) barcode region was sequenced using LepF1 and LepR1 primers (Hebert 2004). The PCR cycle (40 cycles) consisted of 3 minutes initial denaturation at $94^{\circ} \mathrm{C}, 15$ seconds denaturation at $94^{\circ} \mathrm{C}, 30$ seconds annealing at $50^{\circ} \mathrm{C}, 40$ seconds extension at $72^{\circ} \mathrm{C}, 5$ minutes final extension at $72^{\circ} \mathrm{C}$. PCR products were purified using FastAp and Exonuclease (Thermofisher Scientific). Sequencing (forward only) 
was outsourced to Macrogen, Korea. Geneious R8 software was used to manually trim sequences and high quality sequences compared to all barcode records available through the Barcode of Life (BOLD) platform (http://www.boldsystems.org).

Host-plant categories were designated for leaf-miner species for which we had reliable incidence records, that is for those that occurred in more than 10 transects (out of a total of 114) and in at least three sites (out of a total of fourteen) (see Supplementary Material, Figure S1 and S2). Rarely sampled species were not categorised because measures of host range are highly dependent on sampling effort (Novotny \& Basset 2005).

\section{Results}

\section{Leaf-miner and host-plant records}

Throughout this study, we recorded 12679 active leaf-miner individuals. All but 162 (1.3\%) of these individual miners were assigned to a morphospecies. The 162 unassigned miners were associated with twenty-nine different plant species, most of which yielded only one to two individual leaf-miners over the course of the study. In total 12517 leaf-miners were assigned to morphospecies or species (where possible). Fifty-five morphospecies of leafminer were encountered in this study (Table 1). Most were Lepidoptera (41 species), the others being Coleoptera ( 5 species), Diptera (4 species) and a single species of sawfly (Hymenoptera: 'Symphyta'). Four species could not be reared to adult stage and therefore could not be identified to order, but were considered to be unique based on their characteristic mine shapes and host-plant associations. Lepidoptera and Coleoptera voucher specimens have been deposited in the Australian National Insect Collection (ANIC) and Diptera and Hymenoptera voucher specimens in the Queensland Museum.

Twenty of the 41 lepidopteran leaf-miner morphospecies were identified to family, comprising 17 Gracillariidae, two Heliozelidae and one Lyonetiidae. All five species of leafmining beetles collected in this study belong to the family Curculionidae (weevils). Three of the fly species encountered were agromyzids, a family primarily composed of leaf-miners. We also reared a leaf-mining drosophilid, Scaptodrosophila sp., from the fern Blechnum wattsii (Blechnaceae). We recorded a single species of leaf-mining sawfly, Leptoperga brunnea Riek (Pergidae: Phylacteophaginae), mining the leaves of Ripogonum sp. (Ripogonaceae) (Table 1). 
We obtained high-quality CO1 barcodes for 23 individuals belonging to 11 different species (indicated with ${ }^{B}$ in Table 1). Similarities between our sequences and those available through the BOLD database ranged between $88.82 \%$ and $99.23 \%$, with an average of $91.4 \%$ (Supplementary Material, Table S2). Sequences allowed us to confirm identification at the generic or family level only. Even when sequence matches were high (>98\%), only families or genera were assigned to sequences in the BOLD database.

Leaf-mining was recorded for 106 plant species belonging to 44 different families (Table 2). Of these 106 species, four (3.8\%) could not be identified; three of these were represented by a single record and one had a generalist leaf-miner associated with it (Tropicomyza polyphyta (Kleinschmidt)). Three plant species were identified only to genus, but all were unique in the study and therefore treated as distinct species. Two genera were grouped (Carex and Gahnia (Cyperaceae)) as they were not reliably distinguishable in the field. In four cases, two similar plant species in the same genus (of Beilschmiedia, Clematis, Neolitsea and Quintinia) were also grouped because they could not always be distinguished in the field. In most of these cases we were unsure whether the recorded leaf-miner fed on only one or both of the pair of species, except for a miner that was definitely reared from both Quintinia verdonii and $Q$. sieberi. Most plant species that were mined had only one or two leaf-miner species associated with them, apart from Croton verreauxii (Euphorbiaceae), for which we recorded four associated leaf-miner species (Table 2).

\section{Host-plant range}

Host-plant ranges were designated for 24 out of a total of 56 recorded leaf-miner species (43\%). Of these 24 species, 16 used one or two host-plants and the remainder used between three and 17 hosts (Figure 1). Ten species were recorded from a single host-plant, six from two congeneric hosts, four from several confamilial hosts, one from hosts in the same order, and three species used a range of hosts from different orders and were therefore classified as generalists (Table 1).

\section{Discussion}

This study adds substantially to our knowledge of the biology and ecology of leaf-miners in Australia. We discuss host-plant records from this study for each of the four orders of leafmining insects (Lepidoptera, Coleoptera, Diptera and Hymenoptera) below and compare our findings to previous records. 


\section{Lepidoptera}

Leaf-mining occurs in ten lepidopteran families in Australia (Common 1990; Sinclair \& Hughes 2010), three of which were recorded here. For the five lepidopteran leaf-miners identified to species, at least one or a few host-plants were already known, including Caloptilia bryonoma (Turner) (Gracillariidae) on Nothofagus moorei (Nothofagaceae) and Lyonetia lechrioscia Turner (Lyonetiidae) on Quintinia spp. (Quintiniaceae) (based on specimen labels at ANIC). However, we also recorded some new host-plants. Acrocercops chionosema (Turner) (Gracillariidae), for example, has been recorded from Macadamia integrifolia, M. tetraphylla and Stenocarpus salignus (Common 1990), all of which belong to the family Proteaceae. We recorded A. chionosema feeding on three additional species of Proteaceae: Orites excelsus, Helicia glabriflora and Stenocarpus sinuatus. Another gracillariid, Macarostola formosa (Stainton), which has previously been recorded from Acmena smithii (Common 1990), was also recorded in our study on Lophostemon confertus (both Myrtaceae) (Table 2). Heliozelidae sp. A, which was recorded on Psychotria simmondsiana and P. loniceroides, may belong to the genus Holocacista, as a similar or perhaps the same species of moth has previously been collected from $P$. simmondsiana (van Nieukerken \& Geertsema 2015).

\section{Coleoptera}

We only observed leaf-mining curculionids (weevils) and did not encounter any species of Chrysomelidae or Buprestidae, families known to also contain leaf-mining species (Hespenheide 1991). Leaf-mining is quite widespread in the Curculionidae globally but has not been comprehensively assessed. The lifestyle occurs in at least eight tribes of the subfamily Curculioninae (Caldara et al. 2014). It has also been recorded in the supertribes Bariditae and Ceutorhynchitae of the subfamily Conoderinae (Prena et al. 2014) and for the tribes Gonipterini and Hyperini, currently unassigned to subfamily (Oberprieler et al. 2014). The larvae of three species of Cydmaea (Curculioninae: Storeini) have been reported to mine in leaves of Hakea (Proteaceae) (Moore 1966), but the larvae also develop in buds and flowers of these plants and do not specifically appear to be leaf-miners. However, larvae of the genera Syarbis (Gonipterini) and Gerynassa (Hyperini), evidently are true leaf-miners (Oberprieler et al. 2014), as are those of Austrocis and Platynotocis (Viticiini) (Caldara et al. 2014). 
We made 1156 observations of live mines of Platynotocis angulipennis Zimmerman \& Oberprieler feeding on a single host-plant, Polyosma cunninghamii (Escallioniaceae) (Table 1). There are two other described species of Platynotocis in Australia, P. albomaculatus Zimmerman \& Oberprieler and P. pyriformis Lea, for which there are no host records (Pullen et al. 2014), but a related species, Austrocis bicaudatus Zimmerman \& Oberprieler, has been reared from leaf-mines on Elaeocarpus reticulatus (Elaeocarpaceae) (Pullen et al. 2014). There are additional species belonging to the same tribe (Viticiini) in Australia (Pullen et al. 2014), and it is likely that most members of this tribe are leaf-miners (Pullen et al. 2014).

We recorded one species of Orchestes mining in leaves of two species of Argyrodendron (Malvaceae). Although the lifestyle of this genus was previously largely unknown in Australia, Orchestes belongs to the tribe Rhamphini of Curculioninae, which is well known globally for its leaf-mining habits (Caldara et al. 2014). Three further species of weevils collected in this study belong to undescribed genera, and nothing was previously known about their biology. Two belong to the tribe Storeini sensu lato (Storeini sp. A and sp. B), and the third (Genus nr. Thaumastophasis sp.) (Table 1) belongs to the Eristinus group recently classified in the subfamily Molytinae (Pullen et al. 2014).

\section{Diptera}

We recorded three species of Agromyzidae. Tropicomyia polyphyta, which was collected from 17 host-plants in this study, has been previously recorded feeding on many hosts in Australia, including several vegetable crops (Spencer 1977). We provide additional host records for this species, which utilised a range of unrelated plant taxa in our study (Table 1). We recorded Phytoliriomyza queenslandica Spencer mining in leaves of two species of Pittosporum (Pittosporaceae) (Table 2). Another species of Phytoliriomyza has previously been recorded from an unknown species of the same plant family (Spencer 1977), but, as far as we are aware, ours are the first host records for Pittosporum multiflorum and $P$. oreillyanum. Phytomyza vitalbae Kaltenbach, which we recorded from Clematis glycinoides/pickeringii, has previously been recorded from Clematis aristata (Spencer 1963), a species that does occur in the study region (Queensland Herbarium 2013) but was not included in our dataset. Phytomyza vitalbae is a naturalised species introduced from Europe (Spencer 1977). 
Leaf-mining is common in the family Agromyzidae, however, we also recorded a leaf-mining species of Drosophilidae from the fern Blechnum wattsii (Blechnaceae). The leaf-mining habit is rare in Drosophilidae and has been reported for only three genera, Gitona, Drosophila and Scaptomyza, and it is prevalent only in species of Scaptomyza (Scaptomyza) (Ferrar 1987). As far as we are aware, ours is the first record of leaf-mining in the genus Scaptodrosophila. Interestingly, two Hawaiian species of Drosophila, D. apicipuncta Hardy and D. sadleria Bryan, have been bred from the rachises of ferns of the genus Sadleria (also in the family Blechnaceae), with larvae of the former species living in mines (Magnacca \& O'Grady 2009). Larvae of three other Australian species of Scaptodrosophila have been found to feed on living ferns. Two species feed on young fronds of bracken ferns (Pteridium species, Dennstaedtiaceae), groups of larvae of Scaptodrosophila notha (Bock) destroying the central tissues of the rachis and single larvae of Scaptodrosophila megagenys (Bock) feeding externally on the circinate tips (Thomson et al. 1982). Scaptodrosophila inornata (Malloch) larvae recovered from eucalypt litter in the crowns of tree ferns have been shown to feed on the ferns in the laboratory (Bock \& Parsons 1978).

\section{Hymenoptera}

We recorded a single species of leaf-mining sawfly, Leptoperga brunnea, belonging to the subfamily Phylacteophaginae of the family Pergidae. This subfamily is restricted to Australia (Riek 1970; Naumann 1983) and contains only three genera, one of which (Phylacteophaga) includes the eucalypt leaf-blister sawflies, the larvae of which mine the leaves of some myrtaceous species (Mayo et al. 1997).

\section{Conclusions}

Our findings indicate that leaf-miners in Australian subtropical rainforest are, at least locally, relatively host-specific. Insect herbivores involved in such specific interactions may be particularly vulnerable to environmental change (Moir et al. 2015). In Australia, however, we have a limited understanding of host-plant use of insects in natural systems, and a better knowledge of such relationships will enable us to predict how insect-host interactions may be affected by environmental change. Our dataset contained many instances in which only one or two mines were encountered on particular plant species, which may have been because these plant species are rare in our study sites or because they are rarely mined. Given the relative host-specificity of leaf miners, diversity is likely to increase from local to regional scales tracking turnover in plant composition (Novotny \& Miler 2014). Numerous singleton 
observations in our study imply that further field sampling of leaf-miners in Australian rainforest is likely to generate many more host-plant records.

\section{Supporting Information}

Table S1. Data collection sites and dates.

Table S2. Blast results (top 10 similarity hits) of top genetic barcodes. Figure S1. Occurrence of leaf miner morpho/species at sampling sites.

Figure S2. Occurrence of leaf miner morpho/species at sampling sites

\section{Acknowledgments}

This study was funded by the Griffith School of Environment, as part of SM's PhD program. Additional funding was provided by the Environmental Futures Research Institute, The Ecological Society of Australia and the NCCARF Terrestrial Biodiversity Network. RJM was funded by a Royal Society University Research Fellowship. Sincere thanks go to all the volunteers who helped with this project, particularly Elliot Leach, Mariana Pinto, Carlos Torrente, Jonathan McCallum, Casey Hall, Sandra Preston-Hatcher, Patrick O’Connor, Francesca Dem and Heath Cambie. We also thank Louise Ashton, Stephanie Horton and John Hunter for establishing some of the plots that were used in this study. We thank Erik van Nieukerken and Camiel Doorenweerd for identification and DNA barcoding advice. We thank the Queensland Government for providing a permit to work in Lamington National Park (WITK07650710) and the New South Wales Government and the Githabul National Parks Management Committee for providing a license to work in Border Ranges National Park (SL100007).

\section{References}

Basset, Y. 1991. The spatial distribution of herbivory, mines and galls within an Australian rain forest tree. Biotropica, 23, 271-281.

Bairstow, K., Clarke, K., McGeoch, M. \& Andrew, N. 2010. Leaf miner and plant galler species richness on Acacia: relative importance of plant traits and climate. Oecologia, 163, 437-448.

Bock, I.R. \& Parsons, P.A. 1978. The subgenus Scaptodrosophila (Diptera: Drosophilidae). Systematic Entomology, 3, 91-102.

Caldara, R., Franz, N.M., \& Oberprieler, R.G. 2014. 3.7.10 Curculioninae Latreille, 1802. In: Handbook of Zoology. Arthropoda: Insecta. Coleoptera, Beetles. Volume 3: 
Morphology and Systematics (Phytophaga) (eds RAB Leschen \& RG Beutel), pp. 589-628. Walter de Gruyter, Berlin/Boston.

Common, I.F.B. 1990. Moths of Australia. Melbourne University Press, Carlton, Victoria.

Ferrar, P. 1987. A guide to the breeding habits and immature stages of Diptera Cyclorrhapha. Entomonograph, 8, 1-907.

Hebert, P.D.N., Penton, E.H., Burns, J.M., Janzen, D.H., Hallwachs, W. 2004. Ten species in one: DNA barcoding reveals cryptic species in the neotropical skipper butterfly Astraptes fulgerator. Proceedings of the National Academy of Sciences of the United States of America. 101, 14812-14817.

Hespenheide, H.A. 1975. Prey characteristics and predator niche width. Ecology and Evolution of Communities (eds M.L. Cody \& J.M. Diamond), pp. 158-180. Cambridge, Massachusetts.

Hespenheide, H.A. 1991. Bionomics of leaf-mining insects. Annual Review of Entomology, 36, 535-560.

Hoare R.J.B., van Nieukerken E.J. 2013. Phylogeny and host-plant relationships of the Australian Myrtaceae leafmining moth genus Pectinivalva (Lepidoptera, Nepticulidae), with new subgenera and species. ZooKeys, 278, 1-64.

Hoare, R.J.B. 2000. A new genus of primitive Nepticulidae (Lepidoptera) from eastern Australia, with a revised diagnosis of nepticulid subfamilies. Zoological Journal of the Linnean Society, 128, 289-317.

Kaila, L. 2011. Elachistine Moths of Australia (Lepidoptera: Gelechioidea: Elachistidae). Monographs on Australian Lepidoptera. Vol. 11. CSIRO Publishing, Melbourne.

Lambkin, C.L., Fayed, S.A., Manchester, C., La Salle, J., Scheffer, S.J. \& Yeates, D.K. 2008. Plant hosts and parasitoid associations of leaf mining flies (Diptera: Agromyzidae) in the Canberra region of Australia. Australian Journal of Entomology, 47, 13-19.

Magnacca, K.N. \& O'Grady, P.M. 2009. Revision of the modified mouthparts species group of Hawaiian Drosophila (Diptera: Drosophilidae). The ceratostoma, freycinetiae, semifuscata, and setiger subgroups, and unplaced species. University of California Publications in Entomology, 130, 1-94.

Maunsell, S.C., Burwell, C.J., Morris, R.J., McDonald, W.J.F., Edwards, E.D., Oberprieler, R.G. \& Kitching, R.L. 2016. Elevational turnover in the composition of leaf-miners and their interactions with host-plants in Australian subtropical rainforest. Austral Ecology. 41, 238-247.

Maunsell, S.C., Kitching, R.L., Burwell, C.J. \& Morris, R.J. 2015. Changes in host-parasitoid food web structure with elevation. Journal of Animal Ecology, 84, 353-363.

Mayo, G.M., Austin, A.D. \& Adams, M. 1997. Morphological and electrophoretic taxonomy of the Australian eucalypt leaf-blister sawfly genus Phylacteophaga (Hymenoptera: Pergidae): a potential major pest group of eucalypts worldwide. Bulletin of Entomological Research, 87, 595-608.

Moore, K.M. 1966. Observations on some Australian forest insects. 22. Notes on some Australian leaf-miners. Australian Zoologist, 13, 303-349.

Moir, M.L., Vesk, P.A., Brennan, K.E.C., Keith, D.A., McCarthy, M.A. \& Hughes, L. 2011. Identifying and managing threatened invertebrates through assessment of coextinction risk. Conservation Biology, 25, 787-796.

Naumann, I.D. 1983. A new genus of Phylacteophaginae from northern Australia with a key to the genera of the subfamily (Hymenoptera: Tenthredinoidea: Pergidae). Journal of the Australian Entomological Society, 22, 237-242.

Naumann, I.D. (Ed.) 1991. The Insects of Australia: A Textbook for Students and Research Workers, 2nd edn. Melbourne University Press, Melbourne. 
Novotny, V. \& Basset, Y. 2005. Host specificity of insect herbivores in tropical forests. Proceedings of the Royal Society B: Biological Sciences, 272, 1083-1090.

Novotny, V. \& Miller, S. E. 2014. Mapping and understanding the diversity of insects in the tropics: Past achievements and future directions. Austral Entomology, 53, 259-267.

Oberprieler, R.G., Caldara, R., \& Skuhrovec, J. 2014. 3.7.2 Bagoini Thomson, 1859; Gonipterini Lacordaire, 1863; Hyperini Marseul, 1863. In: Handbook of Zoology. Arthropoda: Insecta. Coleoptera, Beetles. Volume 3: Morphology and Systematics (Phytophaga) (eds RAB Leschen \& RG Beutel), pp. 452-476. Walter de Gruyter, Berlin/Boston.

Prena, J., Colonnelli, E., \& Hespenheide, H.A. 2014. 3.7.9 Conoderinae Schoenherr, 1833. In: Handbook of Zoology. Arthropoda: Insecta. Coleoptera, Beetles. Volume 3: Morphology and Systematics (Phytophaga) (eds RAB Leschen \& RG Beutel), pp. 577-689. Walter de Gruyter, Berlin/Boston.

Pullen, K.R., Jennings, D. \& Oberprieler, R.G. 2014. Annotated catalogue of Australian weevils (Coleoptera: Curculionoidea). Zootaxa, 3896, 1-481.

Queensland Herbarium. 2013. HERBRECS database. Queensland Department of Science, Information Technology, Innovation and the Arts (DSITIA).

Riek, E.F. 1970. A redefinition of the subfamily Phylacteophaginae with a description of a new genus and species (Hymenoptera: Symphyta: Pergidae). Journal of the Australian Entomological Society, 9, 215-218.

Sinclair, R.J. \& Hughes, L. 2010. Leaf miners: The hidden herbivores. Austral Ecology, 35, 300-313.

Sinclair, R.J. \& Hughes, L. 2008. Incidence of leaf mining in different vegetation types across rainfall, canopy cover and latitudinal gradients. Austral Ecology, 33, 353-360.

Spencer, K.A. 1963. The Australian Agromyzidae (Diptera, Insecta). Records of the Australian Museum, 25, 305-354.

Spencer, K.A. 1977. A revision of the Australian Agromyzidae (Diptera). Western Australian Museum Special Publications, 8, 1-255.

Thompson, J.A., Jackson, M.J. \& Bock, I.R. 1982. Contrasting resource utilisation in two Australian species of Drosophila Fallen (Diptera) feeding on the bracken fern Pteridium Scopoli. Journal of the Australian Entomological Society, 21, 29-30.

van Nieukerken E.J., \& Geertsema, H. 2015. A new leaf miner on grapevine and Rhoicissus (Vitaceae) in South Africa within an expanded generic concept of Holocacista (Insecta, Lepidoptera, Heliozelidae). ZooKeys, 507, 41-97.

van Nieukerken, E.J., van den Berg, C., \& Hoare, J.B. 2011. A new species of the endemic Australian genus Roscidotoga Hoare from rainforests in southern Queensland (Lepidoptera: Nepticulidae). Tijdschrift voor Entomologie, 154, 193-201. 


\section{$\underline{\text { Tables }}$}

Table 1. Leaf-miner species and host-plant records from Australian subtropical rainforest (Lamington, Border Ranges and Mebbin National Parks (Queensland and New South Wales)). Species or morphospecies in bold are those that were recorded at $>10$ transects in $\geq 3$ sampling sites (see Supplementary Material, Figure S1) and therefore assigned to host-specificity categories. Higher taxa of plants (families and orders) are shown for confamilial, within-order and generalist feeding categories. ${ }^{\mathrm{B}}$ indicates where the identification (at the level preceding ${ }^{\mathrm{B}}$ ) was confirmed with DNA barcoding (see Supplementary Material Table S2).

\begin{tabular}{|c|c|c|c|}
\hline $\begin{array}{l}\text { Order } \\
\text { Family }\end{array}$ & Morpho/species & $\begin{array}{l}\text { Host } \\
\text { category }\end{array}$ & Host-plant/s \\
\hline \multicolumn{4}{|l|}{ Coleoptera } \\
\hline \multirow[t]{5}{*}{ Curculionidae } & Storeini sp. A. & confamilial & $\begin{array}{l}\text { Sapindaceae: Arytera distylis, A. divaricata, Sarcopteryx } \\
\text { stipata, Cupaniopsis flagelliformis var. australis }\end{array}$ \\
\hline & Orchestes sp. & congeneric & $\begin{array}{l}\text { Argyrodendron actinophyllum subsp. actinophyllum, } \\
\text { A. trifoliolatum }\end{array}$ \\
\hline & $\begin{array}{l}\text { Platynotocis angulipennis } \\
\text { Zimmerman \& Oberprieler }\end{array}$ & host-specific & Polyosma cunninghamii \\
\hline & Storeini sp. B. & - & Tasmannia insipida \\
\hline & Genus nr. Thaumastophasis sp. & - & Triunia youngiana \\
\hline \multicolumn{4}{|l|}{ Diptera } \\
\hline Drosophilidae & Scaptodrosophila sp. & - & Blechnum wattsii \\
\hline \multirow[t]{3}{*}{ Agromyzidae } & Tropicomyia polyphyta (Kleinschmidt) & generalist & $\begin{array}{l}\text { Apiales: Cephalaria cephalobotrys, Pennantia } \\
\text { cunninghammii; } \\
\text { Laurales: Wikliea huegeliana, W. austroqueenslandica; } \\
\text { Malpighiales: Streptothamnus moorei, Croton verreauxii; } \\
\text { Liliales: Ripogonum sp.; Gentianales: Atractocarpus } \\
\text { benthamianus; Proteales: Helicia glabriflora; } \text { Cornales: } \\
\text { Alangium villosum subsp. polysmoides; Celastrales: } \\
\text { Denhamia celastroides, Celastrus subspicata; Sapindales: } \\
\text { Anthocarapa nitidula, Synoum glandulosum subsp. } \\
\text { glandulosum; Ericales: Planchonella australis; } \\
\text { Berberidopsidales: Berberidopsis beckleri, and Vine } 1 \\
\text { (unknown taxon) }\end{array}$ \\
\hline & Phytoliriomyza queenslandica Spencer & congeneric & Pittosporum multiflorum, P. oreillyanum \\
\hline & Phytomyza vitalbae Kaltenbach & - & Clematis glycinoides/pickeringii \\
\hline
\end{tabular}

Hymenoptera 


\begin{tabular}{|c|c|c|c|}
\hline Pergidae & Leptoperga brunnea Riek & - & Ripogonum sp. \\
\hline \multirow[t]{17}{*}{$\begin{array}{l}\text { Lepidoptera } \\
\text { Gracillariidae }\end{array}$} & $\begin{array}{l}\text { Gracillariidae sp. F. } \\
\text { Acrocercops }^{\mathrm{B}} \text { chionosema }^{\text {(Turner) }}\end{array}$ & $\begin{array}{l}\text { confamilial } \\
\text { confamilial }\end{array}$ & $\begin{array}{l}\text { Sapindaceae: Arytera distylis, A. divaricata, Mischocarpus } \\
\text { anodontus } \\
\text { Proteaceae: Orites excelsus, Helicia glabriflora, } \\
\text { Stenocarpus salignus, S. sinuatus }\end{array}$ \\
\hline & Gracillariidae $^{\mathrm{B}}$ sp. A. & generalist & $\begin{array}{l}\text { Laurales: Wilkiea huegeliana, W. austroqueenslandica, } \\
\text { Cryptocarya erythroxylon, Beilschmiedia } \\
\text { obtusifolia/elliptica }\end{array}$ \\
\hline & Phyllocnistis $^{\mathrm{B}}$ sp. A. & generalist & Vitales: Cissus antarctica, C. hypoglauca, C. sterculiifolia; \\
\hline & & & $\begin{array}{l}\text { Canellales: Tasmannia insipda; Malpighiales: Breynia } \\
\text { oblongifolia }\end{array}$ \\
\hline & Gracillariidae $^{B}$ sp. B. & congeneric & Atractocarpus benthmianus, A. chartaceous \\
\hline & Gracillariidae sp. C. & congeneric & Planchonella australis, $P$. myrsinfolia \\
\hline & Gracillariidae sp. D. & host-specific & Melodinus australis \\
\hline & Phyllocnistis $^{\mathrm{B}}$ sp. B. & host-specific & Eupomatia laurina \\
\hline & Caloptilia $^{\mathrm{B}}$ bryonoma (Turner) & host-specific & Nothofagus moorei \\
\hline & Gracillariidae sp. $\mathrm{H}$. & - & Acradenia eudiiformis \\
\hline & Phyllocnistis ${ }^{\mathbf{B}}$ sp. D. & - & Stenocarpus salignus, $S$. sinatus \\
\hline & Acrocercops ${ }^{\mathbf{B}}$ trapeziodes (Turner 1894) & - & Embelia australiana \\
\hline & Phyllocnistinae sp. C. & - & Dysoxylum fraserianum \\
\hline & Gracillariidae $^{\mathbf{B}}$ sp. E. & - & Myrsine subsessilis subsp. subsessilis \\
\hline & Macarostola formosa (Stainton) & - & Myrtaceae: Acmenia smithii, Lophostemon confertus \\
\hline & Gracillariidae sp. G. & - & Achronychia bauerlenii, Achronychia pubescens \\
\hline & Phyllocnistinae sp. E. & - & Vine 1 (unknown taxon) \\
\hline \multirow[t]{2}{*}{ Heliozelidae } & Heliozelidae $^{\text {B }}$ sp. A. & congeneric & Psychotria simmondsiana, $P$. loniceroides \\
\hline & Heliozelidae sp. B. & - & Cissus antarctica \\
\hline Lyonetiidae & Lyonetia lechrioscia Turner & congeneric & Quintinia verdonii, $Q$. sieberi \\
\hline \multirow{6}{*}{$\begin{array}{l}\text { Lepidoptera (unknown } \\
\text { family) }\end{array}$} & Lep48 & confamilial & Cyperaceae: Cyperus tetraphyllus, Carex sp., Gahnia sp. \\
\hline & Lep49 & within order & Poales: Oplismenus imbecillus, Cyperus tetraphyllus \\
\hline & Lep27 & host-specific & Croton verreauxii \\
\hline & Lep31 & host-specific & Gynochthodes jasminoides \\
\hline & Lep35 & host-specific & Cleistanthus cunninghamii \\
\hline & Lep46 & host-specific & Elaeodendron australe \\
\hline
\end{tabular}




\begin{tabular}{lll} 
Lep5 & host-specific & Psychotria simmondsiana \\
Lep51 & - & Sapindaceae: Mischocarpus australis, M. anodontus, \\
& & Rhysotoechia sp. \\
Lep32 & - & Polyosma cunninghamii \\
Lep34 & - & Neolitsea australiensis/dealbabta \\
Lep37 & - & Argyrodendron trifoliolatum \\
Lep44 & - & Sloanea woollsii \\
Lep54 & - & Rhysotoechia bifoliolata subsp. bifoliolata \\
Lep50 & - & Syzigium francisii \\
Lep55 & - & Hibbertia scandens \\
Lep39 & - & Pollia crispate \\
Lep29 & - & Croton verreauxii \\
Lep43 & - & Anthocarpa nitidula \\
Lep53 & Polyscias murrayi \\
Lep56 & - & Sarcopteryx stipata \\
Lep28 & - & Croton verreauxii \\
\hline M59 (only parasitoids reared) & - & Doryphora sassafrass \\
M64 & host-specific & Elattostachys nervosa \\
M63 & - & Baloghia inophylla \\
M62 & - & Diospyros pentamera \\
\hline Unknown taxa & - &
\end{tabular}


Table 2. List of host-plants recorded with leaf-miners from Australian subtropical rainforest (Lamington, Border Ranges and Mebbin National Parks (Queensland and New South Wales)). M? indicates a leaf-miner recorded on a host-plant but not identified to morphospecies because no adults reared and not distinguishable on mine structure

\begin{tabular}{|c|c|c|}
\hline Plant Family & Plant species & Leaf-miner morpho/species \\
\hline Anacardiaceae & Euroschinus falcatus & M? \\
\hline Annonaceae & Melodorum leichhardtii & M? \\
\hline Apocynaceae & Melodinus australis & Gracillariidae sp. D. \\
\hline \multirow[t]{2}{*}{ Araliaceae } & Cephalaralia cephalobotrys & Tropicomyza polyphyta \\
\hline & Polyscias murrayi & Lep53 \\
\hline Arecaceae & Calamиs mиelleri & M? \\
\hline Berberidopsidaceae & Berberidopsis beckleri & Tropicomyza polyphyta \\
\hline \multirow[t]{3}{*}{ Blechnaceae } & Blechnum cartilagineum & $\mathrm{M} ?$ \\
\hline & Blechnum wattsii & Scaptodrosophila sp. \\
\hline & Doodia aspera & M? \\
\hline Capparaceae & Capparis arborea & M? \\
\hline \multirow[t]{3}{*}{ Celastraceae } & Celastrus subspicata & Tropicomyza polyphyta \\
\hline & Denhamia celastroides & Tropicomyza polyphyta \\
\hline & Elaeodendron australe var. australe & Lep46 \\
\hline \multirow{2}{*}{ Commelinaceae } & Pollia crispata & Lep39 \\
\hline & Aneilema acuminatum & $\mathrm{M}$ ? \\
\hline Cornaceae & Alangium villosum subsp. polyosmoides & Tropicomyza polyphyta \\
\hline Cucurbitaceae & Zehneria cunninghamii & M? \\
\hline \multirow[t]{2}{*}{ Cyperaceae } & Cyperaceae sp. (Carex or Gahnia) & Lep48; Lep42 \\
\hline & Cyperus tetraphyllus & Lep49 \\
\hline Dilleniaceae & Hibbertia scandens & Lep55 \\
\hline Ebenaceae & Diospyros pentamera & Lep62 \\
\hline Elaeocarpaceae & Sloanea woollsii & Lep44 \\
\hline Escallioniaceae & Polyosma cunninghamii & Platynotocis angulipennis; Lep32 \\
\hline \multirow[t]{4}{*}{ Euphorbiaceae } & Baloghia inophylla & M63 \\
\hline & Croton verreauxii & Lep27; Lep28; Lep29; Tropicomyza polyphyta \\
\hline & Mallotus philippensis & M? \\
\hline & Alchornea ilicifolia & M? \\
\hline Eupomatiaceae & Eupomatia laurina & Phyllocnistis sp. B \\
\hline Fabaceae & Austrosteenisia blackii & M? \\
\hline \multirow[t]{2}{*}{ Flacourtiaceae } & Scolopia braunii & M? \\
\hline & Streptothamnus moorei & Tropicomyza polyphyta \\
\hline \multirow[t]{6}{*}{ Lauraceae } & Beilschmiedia obtusifolia/elliptica & M1? \\
\hline & Cinnamomum oliveri & $\mathrm{M} ?$ \\
\hline & Cryptocarya erythroxylon & Gracillariidae sp. A.; Lep7 \\
\hline & Endiandra crassiflora & M? \\
\hline & Endiandra pubens & Gracillariidae sp. A. \\
\hline & Neolitsea australiensis/dealbata & Lep34 \\
\hline \multirow[t]{2}{*}{ Malvaceae } & $\begin{array}{l}\text { Argyrodendron actinophyllum subsp. } \\
\text { actinophyllum }\end{array}$ & Orchestes sp. \\
\hline & Argyrodendron trifoliolatum & Orchestes sp.; Lep37 \\
\hline \multirow[t]{3}{*}{ Meliaceae } & Anthocarapa nitudula & Tropicomyza polyphyta \\
\hline & Dysoxylum fraserianum & Phyllocnistinae sp. C. \\
\hline & Synoum glandulosum subsp. glandulosum & Tropicomyza polyphyta \\
\hline
\end{tabular}


Wilkiea austroqueenslandica

Wilkiea huegeliana

Doryphora sassafras

Embelia australiana

Myrsine subsessilis subsp. subsessilis

Acmena ingens

Acmena smithii

Gossia acmenoides

Gossia bidwillii

Lophostemon confertus

Syzygium francisii

\begin{tabular}{ll}
\hline Nothofagaceae & Nothofagus moorei \\
\hline Oleaceae & Jasminum simplicifolium subsp. australiense \\
\hline Pennantiaceae & Pennantia cunninghamii \\
\hline Phyllanthaceae & Breynia oblongifolia \\
& Cleistanthus cunninghamii \\
& Glochidion ferdinandi \\
\hline Pittosporaceae & Pittosporum lancifolium \\
& Pittosporum multiflorum \\
& Pittosporum oreillyanum \\
& Pittosporum revolutum \\
\hline Poaceae & Oplismenus imbecillis \\
\hline Proteaceae & Helicia glabriflora \\
& Orites excelsus \\
Stenocarpus salignus \\
\hline Stenocarpus sinuatus \\
\\
Quintiniaceae & Triunia youngiana \\
& Ruintinia verdonii/sieberi \\
&
\end{tabular}

Atractocarpus benthamianus

Atractocarpus chartaceous

Gynochthodes jasminoides

Psychotria loniceroides

Psychotria simmondsiana

\begin{tabular}{lll}
\hline Rununculaceae & Clematis glycinoides/pickeringii & Phytomyza vitalbae \\
\hline Rutaceae & Acradenia euodiiformis & Gracillariidae sp. D. \\
& Acronychia baeuerlenii & Lep47 \\
& Acronychia pubescens & Lep47
\end{tabular}

Gracillariidae sp. B.

Gracillariidae sp. B.

Lep31

Heliozelidae sp. A.

Heliozelidae sp. A.; Lep5

Arytera distylis

Arytera divaricata

Atalaya multiflora

Cupaniopsis flagelliformis var. australis

Diploglottis australis

Elattostachys nervosa

Guioa semiglauca
Gracillariidae sp. A.

Gracillariidae sp. A.

M59

Acrocercops trapeziodes

Lep23

M?

Macarostola formosa

M?

M?

Macarostola formosa

Lep50

Caloptilia bryonoma

$\mathrm{M}$ ?

Tropicomyza polyphyta

Phyllocnistis sp. A.

Lep35

$\mathrm{M}$ ?

M?

Phytoliriomyza queenslandica

Phytoliriomyza queenslandica

M?

Lep49

Acrocercops chionosema; Tropicomyza polyphyta

Acrocercops chionosema

Acrocercops chionosema; Phyllocnistis sp. D.

Acrocercops chionosema; Phyllocnistis sp. D.

Genus nr. Thaumastophasis sp.

Lyonetia lechrioscia

Leptoperga brunnea;

Tropicomyza polyphyta

Storeini sp. A..; Gracillariidae sp. F.

Storeini sp. A.; Gracillariidae sp. F.

M?

Storeini sp. A.

M?

M64

M? 
Mischocarpus anodontus

Mischocarpus australis

Rhysotoechia bifoliolata subsp. bifoliolata

Sarcopteryx stipata

\begin{tabular}{lll}
\hline Sapotaceae & Planchonella australis & Gracillariidae sp. C.; Tropicomyza polyphyta \\
& Planchonella myrsinifolia & Gracillariidae sp. C. \\
\hline Solanaceae & Solanum aviculare & M? \\
& Solanum inaequilaterum & M? \\
\hline Vitaceae & Cissus antarctica & Phyllocnistis sp. A..; Heliozelidae sp. B. \\
& Cissus hypoglauca & Phyllocnistis sp. A. \\
Cissus sterculiifolia & Phyllocnistis sp. A.; Heliozelidae sp. B. \\
\hline Unknown family & Tasmannia insipida & Storeini sp. B.; Phyllocnistis sp. A. \\
& Climbing fern & M? \\
Vine 1 & Tropicomyza polyphyta \\
Vine 2 & M? \\
\hline
\end{tabular}

Gracillariidae sp. F.; Lep51

Lep51

Lep54; Lep51

Storeini sp. A.

Gracillariidae sp. C.; Tropicomyza polyphyta

M?

Phyllocnistis sp. A..; Heliozelidae sp. B. Storeini sp. B.; Phyllocnistis sp. A.

Phyllocnistinae sp. E 


\section{Figures}

Figure 1. Number of host-plant species used by leaf-miner morpho/species, recorded at $>10$ transects $(50 * 3 \mathrm{~m})$ and at $\geq 3$ (out of 14) sampling sites situated in Australian subtropical rainforest (within Lamington, Border Ranges and Mebbin National Parks). 